\title{
Effect of bacterial neuraminidase on the fertilization of rabbit eggs in vitro
}

\author{
Lynn R. Fraser* and Pramila V. Dandekar \\ Department of Obstetrics and Gynecology, Yale University School of Medicine, \\ New Haven, Connecticut, U.S.A.
}

Among the enzymes detected in the mammalian spermatozoon is a neuraminidase which is tightly bound, probably to the inner acrosomal membrane (Srivastava, Zaneveld \& Williams, 1970). The enzyme may play a role in the attachment of the spermatozoon to the zona pellucida, but its exact function is still open to question (Gould, 1973). Because preincubation of unfertilized rabbit eggs in a neuraminidase solution increased the zona resistance to proteolytic digestion, Gould, Zaneveld, Srivastava \& Williams (1971) have suggested that sperm neuraminidase may cause a change in the tertiary and quarternary structure of the protein components of the zona, thereby reducing its penetrability to spermatozoa. The rabbit egg, however, has no detectable zona reaction whereby supernumerary spermatozoa are excluded (Austin, 1961) and Overstreet \& Bedford (1974) have shown that penetration of the rabbit zona by one spermatozoon does not change the penetrability to subsequent spermatozoa.

Soupart \& Clewe (1965) reported that pretreatment of unfertilized rabbit eggs in vitro with bacterial neuraminidase resulted in reduced sperm penetration in vivo and deformation of the zona. The in-vivo fertilization rates of the control (incubated in heat-inactivated enzyme) and experimental eggs were, however, too low to allow meaningful comparison, and were attributed to ageing, manipulation during removal of cells and the in-vitro treatment.

The present experiments were designed to examine the effects of bacterial neuraminidase on the fertilization rate of denuded rabbit eggs in vitro. Previous studies have shown that such eggs are highly fertilizable in an in-vitro system (Fraser, Dandekar \& Vaidya, 1971) and that ageing, particularly for relatively short periods, does not have an appreciable effect (Fraser \& Dandekar, 1973b).

The system used has been fully described elsewhere (Fraser et al., 1971). Egg donors were induced to superovulate with $1 \mathrm{mg} \mathrm{FSH/day} \mathrm{(Armour,} \mathrm{Kankakee,} \mathrm{Illinois)} \mathrm{for} 3$ days and $2.5 \mathrm{mg} \mathrm{LH}$ (Armour), then killed $13 \mathrm{hr}$ after the LH injection. All follicular cells were removed from the eggs by a combination of hyaluronidase treatment ( $150 \mathrm{units} / \mathrm{ml}$ : Worthington) and mechanical agitation (Fraser et al., 1971). Sperm donors were mated 2-3 times with fertile males and killed 14-16 hr post coitum; spermatozoa were recovered by flushing the uterine horns of each doe with $4 \mathrm{ml}$ fertilization medium (Brackett \& Williams, 1968). For most experiments, the purified Type VI neuraminidase (Clostridium perfringens: Sigma; 3.1 units/mg with NAN-lactose) was used except for one experiment with Type V ( 0.08 units/mg with NAN-lactose). Assays of the enzyme preparations, performed by Sigma at the completion of these experiments, verified that the detectable activity corresponded to the stated activity of the samples.

Since the enzyme has an acidic pH optimum, the solutions used to incubate eggs were made up in acidic saline, pH 5.0 (Brackett \& Williams, 1968), the basic salt solution used for the fertilization medium. The two enzyme concentrations used were 0.2 and 0.6 units $/ \mathrm{ml}$. In each experiment some of the neuraminidase solution was heat-inactivated in boiling water for $5 \mathrm{~min}$ and Millipore-filtered to remove the precipitate (after Soupart \& Clewe, 1965). Denuded eggs were incubated in neuraminidase (Group 3a), heated neuraminidase (Group 2) or fertilization medium (controls, Group 1) at $37^{\circ} \mathrm{C}$ for $45 \mathrm{~min}$, washed twice in fertilization medium and transferred to a sperm suspension. To check for parthenogenetic activation, some eggs were incubated in either the low $\mathrm{pH}$ medium (enzyme free) or the neuraminidase solutions (Group 3b), then washed and transferred to sperm-free medium.

\footnotetext{
* Present address: Clinical Research Centre, Watford Road, Harrow, Middlesex HA1 3UJ, England.
} 
Subsequent treatment was the same for all groups. After $4 \mathrm{hr}$, eggs were transferred to culture medium and examined $20 \mathrm{hr}$ later for cleavage. Most of the embryos were prepared for chromosome examination as described by Fraser et al. (1971).

Cleavage rates in the three groups were all high, and there were no significant differences with the low and high concentrations of Type VI neuraminidase (Table 1). Type V neuraminidase $(0.6$ units $/ \mathrm{ml})$ gave similar results in the single experiment performed with it: Group 1, 7/7; Group 2, 16/16; Group 3a, 26/26; Group 3b, 2/17.

Table 1. Cleavage of rabbit eggs per total eggs pretreated with Type VI neuraminidase and exposed to spermatozoa in vitro

\begin{tabular}{|c|c|c|c|c|}
\hline Exp. & $\begin{array}{l}\text { Group } 1 \\
\text { (control) }\end{array}$ & $\begin{array}{c}\text { Group 2 } \\
\text { (heat-inactivated) } \\
\text { neuraminidase) }\end{array}$ & $\begin{array}{c}\text { Group 3a } \\
\text { (neuraminidase+sperm.) }\end{array}$ & $\begin{array}{c}\text { Group 3b } \\
\text { (neuraminidase only) }\end{array}$ \\
\hline \multicolumn{5}{|c|}{ A. 0.2 units neuraminidase $/ \mathrm{ml}$} \\
\hline 1 & $4 / 4$ & $4 / 4$ & $10 / 13$ & $2 / 5$ \\
\hline 2 & $9 / 9$ & $8 / 10$ & $12 / 15$ & $8 / 10$ \\
\hline 3 & $9 / 9$ & $10 / 10$ & $25 / 25$ & $0 / 15$ \\
\hline 4 & $11 / 11$ & $14 / 15$ & $18 / 19$ & $8 / 11$ \\
\hline Total & $33 / 33(100 \%)$ & $36 / 39(92 \%)$ & $65 / 72(90 \%)$ & $18 / 41(44 \%)$ \\
\hline \multicolumn{5}{|c|}{ B. 0.6 units neuraminidase $/ m l$} \\
\hline 1 & $8 / 8$ & $9 / 9$ & $9 / 9$ & $10 / 12$ \\
\hline 2 & $9 / 9$ & - & $26 / 27$ & $0 / 11$ \\
\hline 3 & $4 / 4$ & $5 / 5$ & $26 / 29$ & $2 / 8$ \\
\hline 4 & $11 / 11$ & $17 / 17$ & $19 / 19$ & $6 / 18$ \\
\hline Total & $32 / 32(100 \%)$ & $31 / 31(100 \%)$ & $80 / 84(95 \%)$ & $18 / 49(37 \%)$ \\
\hline
\end{tabular}

Initial experiments showed that neither the acidic medium nor the heat-inactivated enzyme induced activation of the eggs or was in any way deleterious to the eggs. There was, however, a significant incidence of activation, similar in both concentrations of the enzyme, in eggs incubated in neuraminidase without subsequent exposure to spermatozoa.

The majority of chromosome complements in the Group 1 and Group 2 eggs were diploid, although there was a low level of triploidy (Table 2). Of the Group $3 \mathrm{~b}$ embryos, approximately $60 \%$ were diploid and $40 \%$ were haploid. Although a large number of the eggs in Group $3 \mathrm{a}$ were diploid, some were haploid and a sizeable number triploid. Based on the number of cells present in embryos at the time of fixation, haploid embryos tended to cleave more slowly than diploid and triploid ones. The proportion of parthenogenetic embryos developing beyond the 2-celled stage was not significantly lower than that of controls.

Table 2. Chromosome complements of embryos derived from rabbit eggs pretreated with Type VI neuraminidase

\begin{tabular}{llrrrr}
\hline Group & \multicolumn{1}{c}{ Treatment } & $n$ & $2 n$ & $3 n$ & $\begin{array}{c}\text { Lacking } \\
\text { metaphases }\end{array}$ \\
\hline 1 & None (controls) & 0 & 33 & $5(13 \%)$ & 6 \\
2 & Heat-inactivated neuraminidase & 0 & 42 & $8(16 \%)$ & 16 \\
3a & Neuraminidase+spermatozoa & 5 & 57 & $42(40 \%)$ & 31 \\
3b & Neuraminidase only & 11 & 16 & $0(0 \%)$ & 9 \\
\hline
\end{tabular}

Thus preincubation of rabbit eggs in a bacterial neuraminidase solution did not reduce the level of cleavage in vitro; cleavage rates were high in all groups. Contrary to the findings of Soupart \& Clewe (1965), there was no detectable deformation of the zona after pretreatment with either Type V or VI neuraminidase. The finding that neuraminidase treatment of eggs induced a certain level of parthenogenesis suggests that a proportion of those eggs which cleaved after enzyme treatment and 
exposure to spermatozoa were in fact activated and not fertilized. As seen in Table 1, high cleavage rates were obtained in two individual experiments when eggs were mixed with spermatozoa, while no cleavage ensued when eggs were treated with enzyme alone. In the remaining experiments a relatively high level of parthenogenesis was found, thus suggesting that the actual level of fertilization was considerably reduced compared with control eggs.

The chromosome complements of the embryos in Group 3a were unusual. Since the eggs were effectively aged in vitro during the preincubation and washing, some triploidy is not an unexpected result (Fraser \& Dandekar, 1973b) and a low level of triploidy is usually found even when eggs that are not aged are used (Fraser \& Dandekar, 1973a). The occurrence of triploidy in the neuraminidasetreated eggs was significantly higher $\left(\chi^{2}, P<0.005\right)$ than in the other groups. Since the majority of activated embryos were diploid, the enzyme might have interfered with extrusion of the second polar body. This would suggest that the enzyme interacted with the vitelline membrane instead of or in addition to the zona pellucida. The possibility that some neuraminidase-vitelline membrane interaction might occur was suggested by Gould (1973), although there was little experimental evidence to support the idea.

Gould, Srivastava, Cline \& Williams (1971) incubated rabbit eggs in rabbit sperm neuraminidase before exposure to capacitated spermatozoa in vitro. Fertilization was very much reduced $(<5 \%)$ in the enzyme-treated eggs. This low level, compared with the present study, is perhaps explained by the apparent difference in enzyme specificities with the bacterial neuraminidase preferentially cleaving the $2 \rightarrow 3$ sialic acid linkages and the sperm enzyme cleaving the $2 \rightarrow 6$ linkages (Srivastava et al., 1970). Since the eggs in the study of Gould et al. (1971) were apparently still within the cumulus mass when exposed to the sperm neuraminidase, some of the difference in results may reflect an interaction between the follicular cells and the sperm neuraminidase. The presence of the cells might also interfere with interaction between the enzyme and the vitelline membrane.

We thank Mrs Kathy Petzold for expert technical assistance. This work was supported by a Ford Foundation grant.

\section{References}

Austin, C. (1961) The Mammalian Egg. Blackwell Scientific Publications, Oxford.

BracketT, B. \& Williams, W. (1968) Fertilization of rabbit ova in a defined medium. Fert. Steril. 16, 144-155.

Fraser, L. \& Dandekar, P. (1973a) Fertilization of rabbit eggs in vitro without supplemental $\mathrm{CO}_{2}$ in the atmosphere. J. Reprod. Fert. 33, 159-161.

FRASER, L. \& DANDEKAR, P. (1973b) The effects of aging on in vitro fertilization of rabbit eggs and subsequent embryonic development. $J$. exp. Zool. 184, 303-312.

Fraser, L., Dandekar, P. \& Vaidya, R. (1971). In vitro fertilization of tubal rabbit ova partially or totally denuded of follicular cells. Biol. Reprod. 4, 229233.

GouLd, K. (1973) Studies on the interaction of mammalian gametes in vitro. Ph.D. thesis, University of London.
Gould, K., Srivastava, P., Cline, E. \& Williams, W. (1971) Inhibition of in vitro fertilization of rabbit ova with naturally occurring antifertility agents. Contraception 3, 261-267.

Gould, K., Zaneveld, L., Srivastava, P. \& Williams, W. (1971) Biochemical changes in the zona pellucida of rabbit ova induced by fertilization and sperm enzymes. Proc. Soc. exp. Biol. Med. 136, 6-10.

OVERSTREeT, J. \& BEDFord, J. (1974) Comparison of the penetrability of the egg vestments in follicular oocytes, unfertilized and fertilized ova of the rabbit. Devl Biol. 41, 185-192.

Soupart, P. \& Clewe, T. (1965) Sperm penetration of rabbit zona pellucida inhibited by treatment of ova with neuraminidase. Fert. Steril. 16, 677-682.

Srivastava, P., Zaneveld, L. \& Williams, W. (1970) Mammalian sperm acrosomal neuraminidase. Biochem. Biophys. Res. Commun. 39, 575-582. 